\title{
Synthesis of Symmetrical Multichromophoric Bodipy Dyes and Their Facile Transformation into Energy Transfer Cassettes**
}

\author{
O. Altan Bozdemir, ${ }^{[a]}$ Yusuf Cakmak, ${ }^{[a]}$ Fazli Sozmen, ${ }^{[b]}$ Tugba Ozdemir, ${ }^{[a]}$ \\ Aleksander Siemiarczuk, ${ }^{[c]}$ and Engin U. Akkaya ${ }^{*[a, d]}$
}

\begin{abstract}
Multichromophoric boron-dipyrromethene (Bodipy) dyes synthesized on phenylene-ethynylene platforms have been be converted to energy transfer cassettes in a one-step chemical transformation. Excitation energy transfer processes in these highly symmetrical derivatives were studied in detail, including time-re-
\end{abstract}

solved fluorescence spectroscopy techniques. Excitation spectra and the emission lifetimes suggest efficient energy transfer between the donor and

Keywords: dyes/pigments • energy transfer $\cdot$ fluorescence spectroscopy $\cdot$ fluorophores $\cdot$ Sonogashira coupling acceptor chromophore. These novel energy transfer cassettes, while highlighting a short-cut approach to similar energy transfer systems, could be useful as large pseudo-Stokes shift multichromophoric dyes with potential applications in diverse applications.

\section{Introduction}

Bodipy dyes, which are also known as boradiazaindacenes or boron dipyrrins, have attracted great interest in recent years. ${ }^{[1]}$ This renewed interest is primarily due to advances in the methodologies for the transformation ${ }^{[2-6]}$ of the parent structure and the increasing diversity of potential applications. ${ }^{[7-10]}$ In addition to being a useful chromophores/ fluorophores, Bodipy dyes, with their unique arrangement of substituent groups held at fixed angles in certain derivatives, have great potential as a scaffold or building block in complex supramolecular architectures.

[a] Dr. O. A. Bozdemir, Y. Cakmak, T. Ozdemir, Prof. Dr. E. U. Akkaya UNAM-Institute of Materials Science and Nanotechnology Bilkent University, 06800 Ankara (Turkey)

Fax: (+90)312-266-4068

E-mail: eua@fen.bilkent.edu.tr

[b] F. Sozmen

Department of Chemistry, Faculty of Arts and Sciences

Akdeniz University, 07058 Antalya (Turkey)

[c] Dr. A. Siemiarczuk

PTI Fast Kinetics Laboratory

347 Consortium Road, N6E 2S8, London, ON (Canada)

[d] Prof. Dr. E. U. Akkaya

Department of Chemistry, Bilkent University, 06800 Ankara (Turkey)

[**] Bodipy=boron-dipyrromethene, 4,4-difluoro-4-bora-3a,4a-diaza-s-indacene.

Supporting information for this article is available on the WWW under http://dx.doi.org/10.1002/chem.200903449.
A few years ago, we demonstrated that a dimeric Bodipy structure can be easily transformed into an energy transfer cassette by a selective reaction on one of the Bodipy units. $^{[7 b]}$ The Knoevenagel reaction of one of the methyl groups on the Bodipy core results in the placement of a $(E)$ phenylethenyl group that extends the conjugation and shifts the absorbance and emission bands towards the red end of the visible spectrum by $60-100 \mathrm{~nm}$. These two different dyes then constitute an energy transfer pair with close proximity and significant spectral overlap. The energy transfer in this kind of cassettes may have contributions from both throughspace and through-bond interactions, usually resulting in a very efficient energy transfer.

In the work described herein, we want to demonstrate that similar efficient energy transfer could take place in other multi-chromophoric Bodipy dyes assembled on phenylene-ethynylene cores. Even though 1,7-methyl groups on the Bodipy structures enforce a near perpendicular arrangement of the Bodipy "plane" and the meso-phenyl substituent, ${ }^{[7 \mathrm{~b}, j]}$ some conjugation is expected and through-bond energy transfer cannot be discarded. The first set of targeted molecules was the symmetrical oligo-Bodipy compounds 24. In these compounds, Bodipy units are placed on an ethynyl-substituted benzene at $(1,4),(1,3,5)$, and $(1,2,4,5)$ substitution patterns. The spectral characteristics of the Bodipy dyes are not affected significantly, which is an indication of minor (if any at all) interchromophoric interactions in these dyes. In other words, they behave not much different than individual Bodipy units. Following spectral characterization, these 


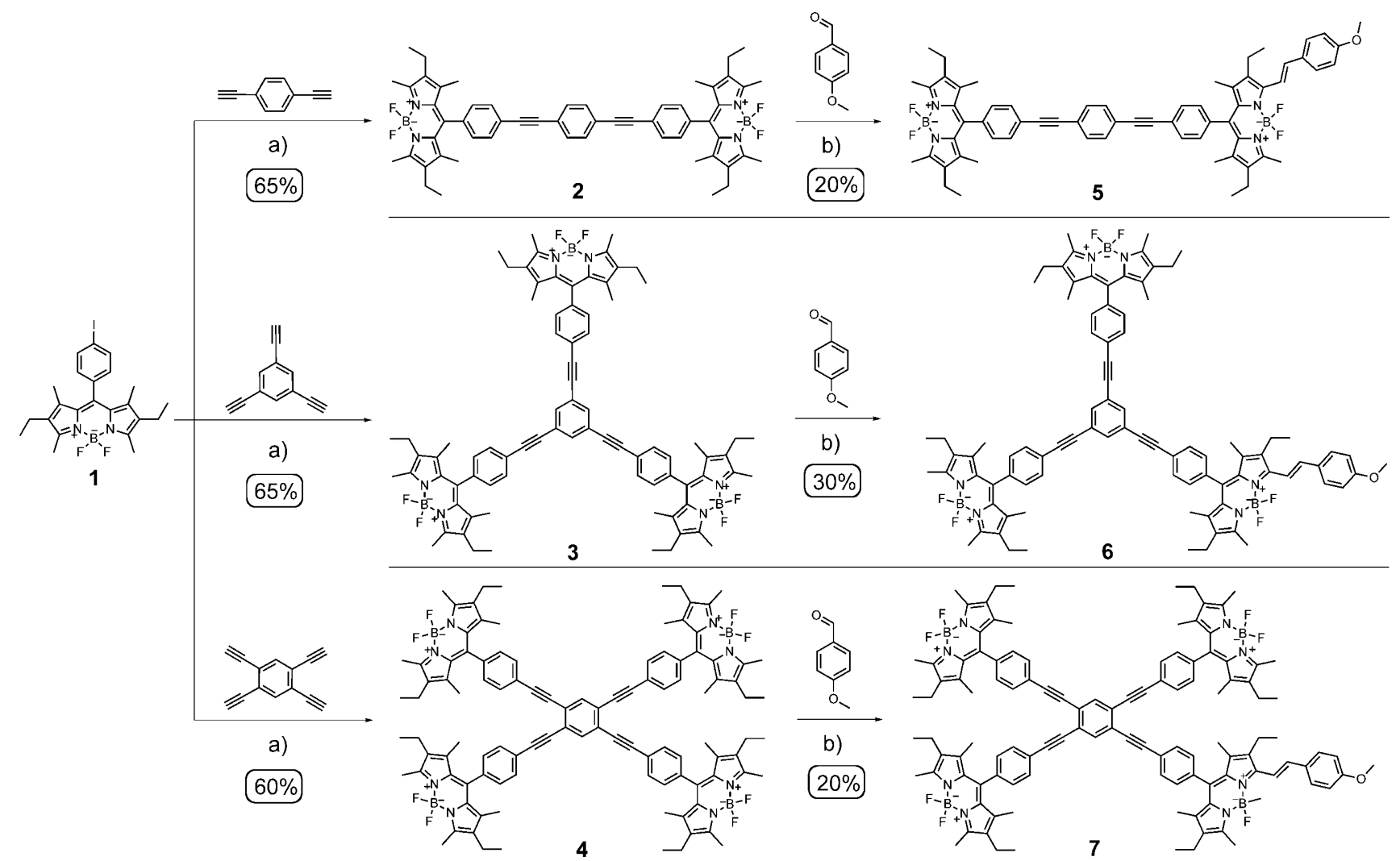

Scheme 1. a) $\left[\mathrm{Pd}\left(\mathrm{PPh}_{3}\right)_{4}\right]$, CuI, THF/toluene/triethylamine, $80^{\circ} \mathrm{C}$ for $20 \mathrm{~min}$ then RT, 1 day. b) Acetic acid, piperidine/benzene, reflux.

compounds were converted into energy transfer cassettes in one step by a Knoevenagel reaction with a small amount of $p$-methoxybenzaldehyde. The use of excess aldehyde allowed the production of other extended conjugation (styrylBodipy) dyes at different positions, creating a complex reaction mixture. These new energy transfer cassettes were then analyzed by spectroscopic methods, showing very efficient energy transfer, with an approximate pseudo-Stokes shift of $2400 \mathrm{~cm}^{-1}$. Bodipy dyes with their inherent desirable properties such as high quantum yields and large extinction coeffi-

Abstract in Turkish: Fenilenetilen platformu üzerinde sentezlenen multikromoforik Bodipy boyarmaddeleri, tek basamakl bir kimyasal transformasyonla enerji transferi kasetlerine dönüştürülmüştür. Zaman ayrimlı floresans spektroskopisi tekniklerinin de içinde bulunduğu yöntemlerle, yüksek simetri öğeleri bulunduran bu türevlerdeki eksitasyon enerjisi transferi süreçleri ayrıntıl olarak çalışılmıştır. Eksitasyon spektrumları ve emisyon ömürlerindeki değişim, donör ve akseptör kromoforları arasında etkin bir enerji transferi olduğu$n u$ düşündürmektedir. Bu yeni enerji transfer kasetleri, benzer enerji transfer sistemlerine kolay bir geçiş yolu göstermekle birlikte, pek çok farklı alanda potansiyel uygulamaları olabilecek, büyük pseudo-Stokes kayması değerlerine sahip multikromoforik boyarmaddeler olarak da yararlı olabilirler. cients would be even more valuable when endowed with such relatively large Stokes' shift values, compared to typical $400 \mathrm{~cm}^{-1}$ values for unmodified Bodipy fluorophores.

\section{Results and Discussion}

Synthesis of the multichromophoric dyes: 8-Iodophenyl-substituted Bodipy $\mathbf{1}$ is a known compound. Our strategy involved the Sonogashira coupling of this Bodipy dye with different ethynylbenzenes with various substitution patterns. Thus, in order to obtain the simplest dye of the series (2), we carried out a Sonogashira coupling between the Bodipy $\mathbf{1}$ and $p$-diethynylbenzene. For the other dyes of higher substitution levels, we used 1,3,5-triethynylbenzene and 1,2,4,5tetraethynylbenzene to generate $\mathbf{3}$ and $\mathbf{4}$, respectively (Scheme 1). The reactions were initiated by heating the 8-iodophenyl-Bodipy and the ethynylbenzenes in THF/toluene in the presence of tetrakis(triphenyl)palladium, cuprous iodide, and triethylamine at $80^{\circ} \mathrm{C}$, for $20 \mathrm{~min}$ and then the stirring was continued at room temperature for $24 \mathrm{~h}$. Once the products of the Sonogashira reaction were purified (24), they were subjected to Knoevenagel conditions (aromatic aldehyde, piperidine, acetic acid, reflux under azeotropic removal of water) using one equivalent of $p$-methoxybenzaldehyde (Scheme 1). The products 5-7 were purified by silica-gel chromatography. 
Absorption and steady state fluorescence characterization: The absorption spectra of the dyes $\mathbf{2}, \mathbf{3}$, and $\mathbf{4}$ were acquired in $\mathrm{CHCl}_{3}$ in dilute solutions (Table 1 ). The absorption $\lambda_{\max }$ is

Table 1. Photophysical data of Bodipy derivatives in $\mathrm{CHCl}_{3}$ at $25^{\circ} \mathrm{C}$.

\begin{tabular}{llcllllll}
\hline & $\begin{array}{l}\lambda_{\text {abs }} \\
{[\mathrm{nm}]}\end{array}$ & $\begin{array}{c}\varepsilon_{\text {max }}^{[\mathrm{a}]} \\
{\left[\mathrm{M}^{-1} \mathrm{~cm}^{-1}\right]}\end{array}$ & $\begin{array}{l}\lambda_{\text {ems }} \\
{[\mathrm{nm}]}\end{array}$ & $\begin{array}{l}\tau \\
{[\mathrm{ns}]}\end{array}$ & $\Phi^{[\mathrm{a}, \mathrm{b}]}$ & $\begin{array}{l}\lambda_{\text {ems }} \\
{[\mathrm{nm}]}\end{array}$ & $\begin{array}{l}\tau \\
{[\mathrm{ns}]}\end{array}$ & $\Phi^{[\mathrm{a}, \mathrm{c}]}$ \\
\hline $\mathbf{1}$ & 528 & 62000 & 540 & 4.3 & 0.85 & - & - & - \\
$\mathbf{2}$ & 528 & 103000 & 540 & 4.5 & 0.74 & - & - & - \\
$\mathbf{3}$ & 528 & 296000 & 545 & 4.3 & 0.49 & - & - & - \\
$\mathbf{4}$ & 529 & 370000 & 545 & 4.2 & 0.57 & - & - & - \\
$\mathbf{5}$ & 529 & 82000 & 545 & $<0.1$ & 0.03 & 606 & 4.6 & 0.24 \\
& 591 & 84000 & - & - & - & - & - & 0.37 \\
$\mathbf{6}$ & 529 & 218000 & 545 & $<0.1$ & 0.1 & 606 & 4.2 & 0.29 \\
& 592 & 98000 & - & - & - & - & - & 0.32 \\
$\mathbf{7}$ & 529 & 297000 & 545 & $<0.1$ & 0.1 & 608 & 4.1 & 0.31 \\
& 592 & 93000 & - & - & - & - & - & 0.42
\end{tabular}

[a] Determined in $\mathrm{CHCl}_{3}$ solution. [b] Rhodamine $6 \mathrm{G}$ in water $\left(\Phi_{\mathrm{f}}=\right.$ $0.95)$ was used as reference.[c] Sulforhodamine 101 hydrate in ethanol $\left(\Phi_{\mathrm{f}}=0.90\right)$ was used as reference.

unchanged compared to the simpler Bodipy dye 1, at $528 \mathrm{~nm}$ (529 nm for 4). This suggests that ethynylphenyl spacers place the chromophores at a distance, at which interchromophoric interactions are minimal. Extinction coefficients show an increasing trend as the number of Bodipy units increase, reaching a very large value of $370000 \mathrm{~cm}^{-1} \mathrm{M}^{-1}$ for compound 4. Steady-state emission spectroscopy of the novel chromophores shows a typical Bodipy emission centered around $540 \mathrm{~nm}$ (2) and $545 \mathrm{~nm}$ (compound $\mathbf{3}$ and 4), with no significant change in the peak shape or width. High quantum yields were conserved in all three compounds ( 0.74 for $2,0.49$ for $\mathbf{3}$, and 0.57 for 4 ). The energy transfer cassettes obtained from these three compounds had interesting properties: in the absorption spectra, all three had two distinct peaks indicative of two different classes of Bodipy dyes. The absorption spectra of these compounds are presented in Figure 1, together with that of a reference compound styryl-bodipy $\mathbf{8} ;{ }^{[2 \mathrm{c}]}$ the spectra show the progressive dominance of the shorter wavelength peak as

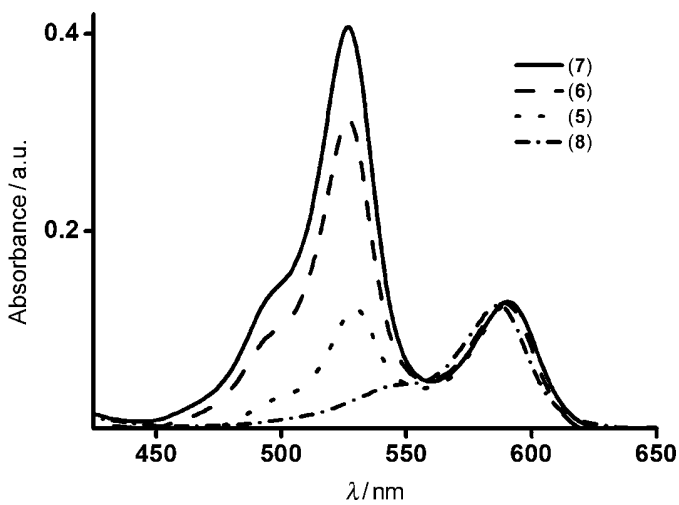

Figure 1. Absorbance spectra of compounds 5, 6, 7, and $\mathbf{8}$ at equal absorbances at $591 \mathrm{~nm}$ in $\mathrm{CHCl}_{3}$ (concentrations are $5.96 \times 10^{-7} \mathrm{M}, 4.97 \times 10^{-7} \mathrm{M}$, $5.25 \times 10^{-7} \mathrm{M}, 5.23 \times 10^{-7} \mathrm{M}$, respectively). the number of Bodipy units increases. The concentrations were adjusted so that the longer wavelength absorptions at $591 \mathrm{~nm}$ were equalized. Emission characteristics of the energy transfer cassettes are presented in comparison to two reference compounds ( $\mathbf{1}$ and $\mathbf{8})$.

Emission spectra of $\mathbf{1}, \mathbf{5}$, and $\mathbf{8}$ are given in Figure 2. To facilitate comparison and provide an easy handle on the extent of energy transfer, concentrations were adjusted to equal absorbance values at $528 \mathrm{~nm}$ (excita-
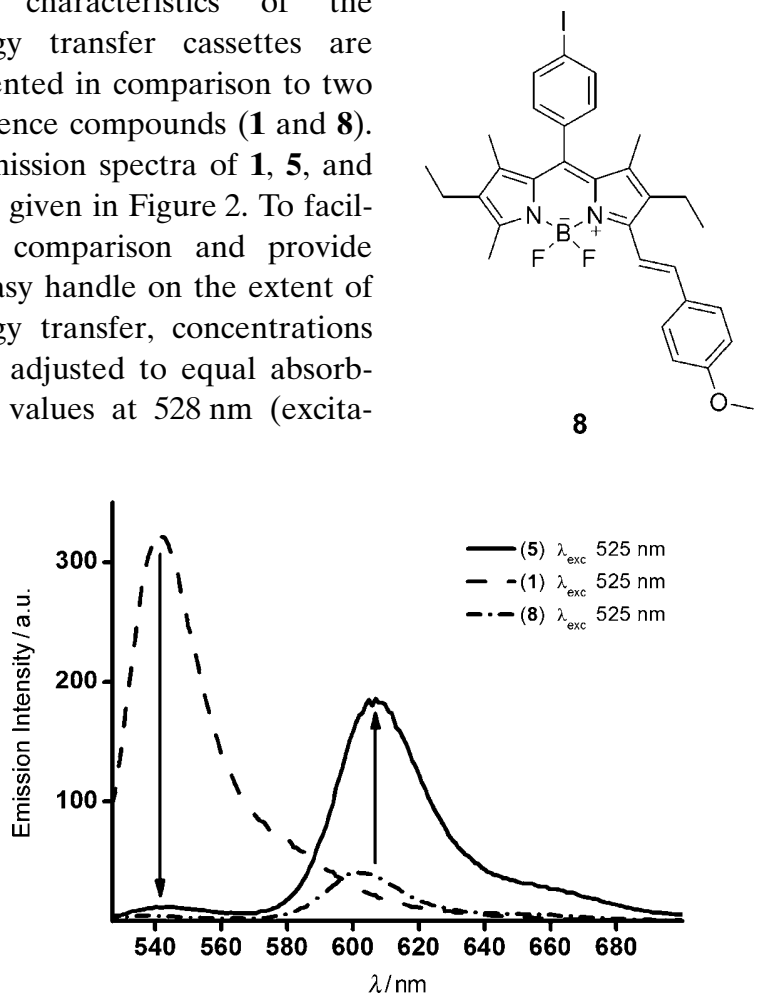

Figure 2. The emission spectra of $\mathbf{1}, \mathbf{5}$, and $\mathbf{8}$ at equal absorbances at $528 \mathrm{~nm}$ for $\mathbf{1}$ and $\mathbf{5}$ and at $591 \mathrm{~nm}$ for $\mathbf{5}$ and $\mathbf{8}$ in $\mathrm{CHCl}_{3}$

tion wavelength for the shorter wavelength absorbing "antenna" Bodipy) for $\mathbf{1}$ and $\mathbf{5}$, or at $591 \mathrm{~nm}$ for the styrylBodipy (excitation wavelength). The data shows that the emission from the shorter wavelength absorbing "antenna" chromophore in compound $\mathbf{5}$ is reduced significantly compared to that of the reference compound $\mathbf{1}$. On the other hand, emission at the longer wavelength band $\left(\lambda_{\max } 611 \mathrm{~nm}\right)$ is increased considerably, demonstrating an antenna effect, and efficient energy transfer. Figure 3 and 4 show a similar comparative assessment of compounds $\mathbf{1}, \mathbf{6}, \mathbf{8}$ (Figure 3 ) and

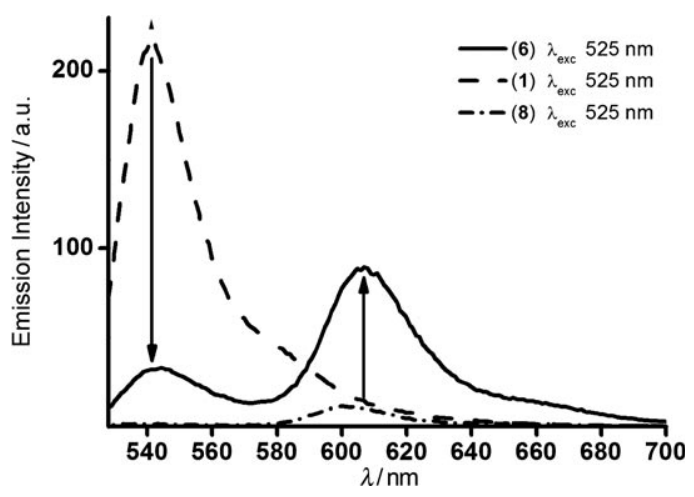

Figure 3. The emission spectra of $\mathbf{1}, \mathbf{6}$, and $\mathbf{8}$ at equal absorbances at $528 \mathrm{~nm}$ for $\mathbf{1}$ and $\mathbf{6}$ and at $591 \mathrm{~nm}$ for $\mathbf{6}$ and $\mathbf{8}$ in $\mathrm{CHCl}_{3}$. 


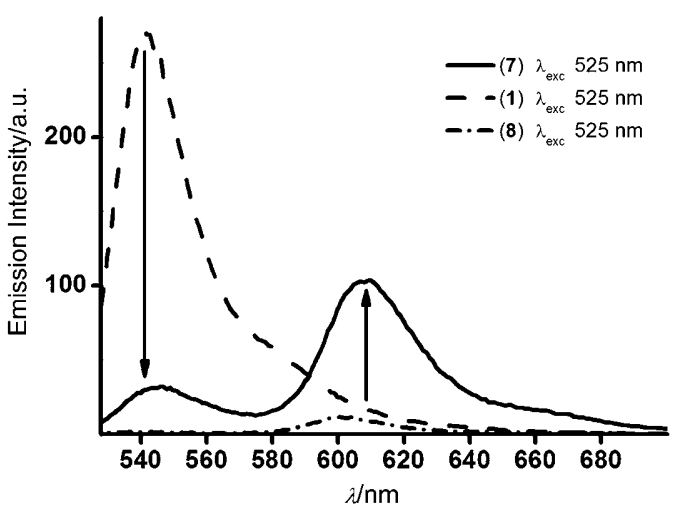

Figure 4. The emission spectra of $\mathbf{1}, \mathbf{7}$, and $\mathbf{8}$ at equal absorbances at $528 \mathrm{~nm}$ for $\mathbf{1}$ and $\mathbf{7}$ and at $591 \mathrm{~nm}$ for $\mathbf{7}$ and $\mathbf{8}$ in $\mathrm{CHCl}_{3}$.

1, 7, 8 (Figure 4). In both dyads 6 and 7, the emission from the energy donor Bodipy is diminished, whereas the longer wavelength emission is increased at equal absorbance concentrations of compounds $\mathbf{6}$ and $\mathbf{7}$ compared to 8. Figure 5

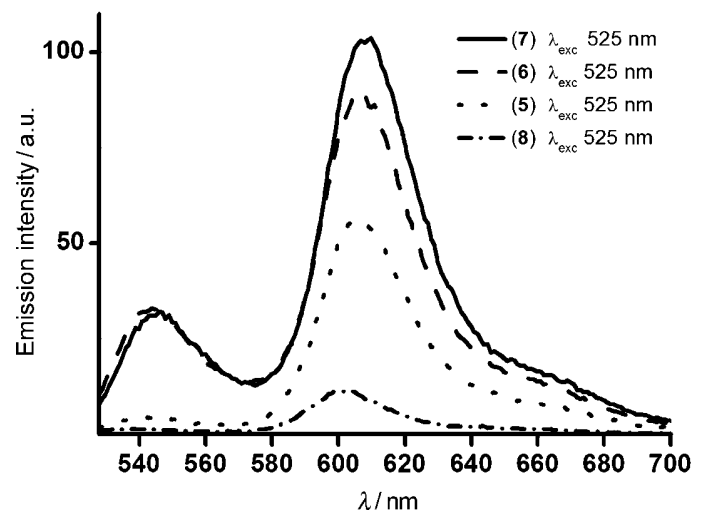

Figure 5. The emission spectra of $\mathbf{5}, \mathbf{6}, \mathbf{7}$, and $\mathbf{8}$ at equal absorbances at $591 \mathrm{~nm}$ in $\mathrm{CHCl}_{3}$.

shows another view of the antenna effect; when compounds $5,6,7$, and $\mathbf{8}$ were dissolved in $\mathrm{CHCl}_{3}$ to form dilute solutions with equal absorbances at 591 (energy acceptor styrylBodipy absorption peak) as the number of energy donor Bodipy units increase, the antenna effect also increases steadily, reaching tenfold in compound 8. Since the short wavelength and long wavelength emission peaks are somewhat resolved in the emission spectrum, separate quantum yields for both emissions can be defined and calculated (Table 1). The data clearly show quenching of the donor dyes as expected. Excitation spectra (Figure 6) also corroborate energy transfer between the donor and acceptor chromophores: the emission data from the longer wavelength emitting styryl-Bodipy dye are acquired and in the overlay spectra shown in Figure 6, shorter wavelength excitation peaks become more dominant in the spectra as the number of donor units increase. Concentration-dependent emission spectra, and spectra taken at different lamp intensities, do

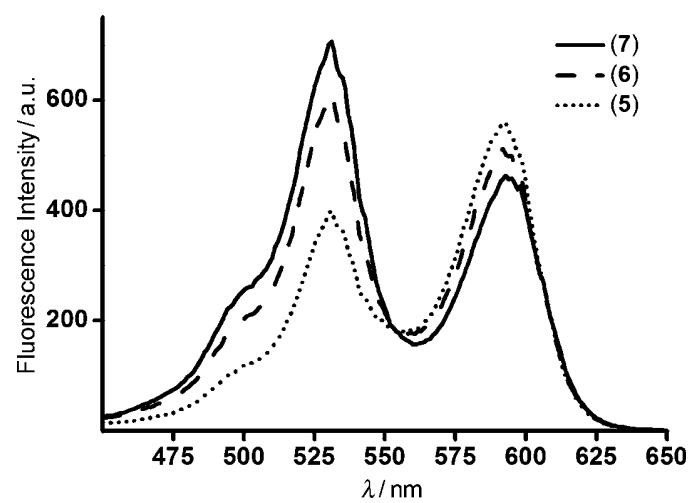

Figure 6 . The excitation spectra of $\mathbf{5}, \mathbf{6}$, and $\mathbf{7}$ at equal absorbances at $591 \mathrm{~nm}$ in $\mathrm{CHCl}_{3}$. The emission data were collected at $606 \mathrm{~nm}$.

not result in qualitatively different spectra, eliminating any complications due to multiphoton processes.

Time-resolved fluorescence spectroscopy: Emission lifetime data provide solid evidence for the energy-transfer phenomena. The emission lifetimes for compounds $\mathbf{2}, \mathbf{3}$, and $\mathbf{4}$ are essentially identical to each other and the reference Bodipy dye 1 (around $4.3 \mathrm{ns).} \mathrm{In} \mathrm{the} \mathrm{energy-transfer} \mathrm{cassettes} \mathrm{5,} \mathbf{6}$, and $\mathbf{7}$, the emission from the donor dye is very short lived, under the detection limit of the instrumental setup $(<$ $0.1 \mathrm{~ns})$ The emission lifetime from the acceptor styrylbodipy dyes have comparable lifetimes (in the range of 4.1$4.6 \mathrm{~ns})$ to the other styryl-Bodipy dyes. ${ }^{[2 \mathrm{a}, 10 \mathrm{f}]}$ Thus, the energy transfer rate constants for the Förster model is calculated to be larger than $9.8 \times 10^{9} \mathrm{~s}^{-1}$ for compounds $\mathbf{5}, \mathbf{6}$, and 7. These values point to energy transfer efficiency values over $97 \%$.

Potential of "post-assembly" modification in light-harvesting systems and energy-transfer cassettes: As demonstrated here, Bodipy dyes allow a one-step modification that transforms oligomeric dye assemblies (covalent or non-covalent) into efficient light harvesters or energy-transfer (ET) cassettes. This could be a significant synthetic advantage, essentially resulting in a highly convergent synthesis. In most other ET cassettes, the dyes have to be selected and appropriately modified before they are tethered together by a linker. Considering the growing versatility of the Bodipy dyes, ${ }^{[12]}$ ET cassettes with large pseudo-Stokes shifts covering the entire spectrum between $560-800 \mathrm{~nm}$ seems to be possible.

\section{Conclusion}

Versatile Bodipy chemistry allows the straightforward construction of multichromophoric systems. In this study, we first demonstrated the feasibility of the synthesis of multiple Bodipy-carrying phenylethynyl scaffolds. Our work shows that despite their proximity, the Bodipy units, even in the 
most densely functionalized derivative $\mathbf{7}$, behaved as individual entities, with unaltered absorption, emission, and lifetime characteristics. These compounds then are converted to efficient energy-transfer cassettes in just one simple step by simple high-yield condensation reactions. We have also shown that the energy transfer between the unmodified Bodipy dyes and the styryl-appended bodipy dyes takes place an efficiency greater than $99.5 \%$. The result is the production of large extinction coefficient energy-transfer cassettes with large antenna effects (signal ampilification values). The resulting pseudo-Stokes shift is much larger than that of a regular Bodipy dye, enhancing the chances of their potential as bright fluorescent dyes, which could be useful in many applications including DNA sequencing and protein labeling. The Knoevenagel reaction leading to styryl-Bodipys can also be carried out with carboxy-functionalized benzaldehydes, which can be converted to aminereactive NHS esters following a simple procedure. Further work in functionalization of these dyes, would facilitate such applications. The reaction of additional methyl groups in the Knoevenagel reactions, or the replacement of fluorine atoms in any one of the Bodipy units with bioconjugatable units are other likely paths for such functionalizations. In any case, the future looks bright for styryl-Bodipy based energy-transfer cassettes.

\section{Experimental Section}

General: ${ }^{1} \mathrm{H}$ NMR and ${ }^{13} \mathrm{C}$ NMR spectra were recorded on a Bruker DPX-400 (operating at $400 \mathrm{MHz}$ for ${ }^{1} \mathrm{HNMR}$ and $100 \mathrm{MHz}$ for ${ }^{13} \mathrm{C} \mathrm{NMR}$ ) in $\mathrm{CDCl}_{3}$ and $\left[\mathrm{D}_{6}\right] \mathrm{DMSO}$ solvents with tetramethylsilane as internal standard. All spectra were recorded at $25^{\circ} \mathrm{C}$ and coupling constants ( $J$ values) are given in Hz. Chemical shifts are given in parts per million (ppm). Absorption spectra were performed by using a Varian Cary-100 spectrophotometer. Fluorescence measurements were conducted on a Varian Eclipse spectrofluorometer. The Fluorescence decay measurements were carried out with the TM-3 LaserStrobe Time-Resolved Fluorometer utilizing a pulsed nitrogen/dye laser excitation and the stroboscopic detection system. The dye laser excitation was at 526 and $590 \mathrm{~nm}$. The instrument response function was measured with an aqueous Ludox solution. The decays were analyzed with a multiexponential fitting function by iterative reconvolution and chi-square minimization. Mass spectra were recorded at the Ohio State University Mass Spectrometry and Proteomics Facility, Ohio, USA. Reactions were monitored by thin layer chromatography using Merck TLC Silica gel $60 \mathrm{~F}_{254}$ and Merck Aluminium Oxide $60 \mathrm{~F}_{254}$. Silica gel column chromatography was performed over Merck Silica gel 60 (particle size: $0.040-0.063 \mathrm{~mm}$, 230-400 mesh ASTM). 4,4-Difluoro-8-(4'-iodophenyl)-2,6-diethyl-1,3,5,7tetramethyl-4-bora-3a,4a-diaza-s-indacene $(\mathbf{1}){ }^{[7 \mathrm{k}]}$ compound $\mathbf{2}^{\left[{ }^{[7 \mathrm{c}]}\right.} 4,4$-difluoro-8-(4'-iodophenyl)-2,6-diethyl-1-(4'-methoxystyryl)-3,5,7-trimethyl4-bora-3a,4a-diaza-s-indacene $\quad(\mathbf{8}),{ }^{[2 c]} \quad 1,3,5$-triethynylbenzene, ${ }^{[11]}$ and 1,2,4,5-tetraethynylbenzene ${ }^{[11]}$ were synthesized according to literature methods. Anhydrous tetrahydrofuran was obtained by refluxing over sodium/benzophenone prior to use. All other reagents and solvents were purchased from Aldrich and used without further purification.

Synthesis of compound 3: In a $50 \mathrm{~mL}$ Schlenk tube were added 1 $(0.415 \mathrm{mmol}, 0.21 \mathrm{~g}), 1,3,5$-triethynylbenzene $(0.115 \mathrm{mmol}, 17.3 \mathrm{mg})$, [Pd$\left.\left(\mathrm{PPh}_{3}\right)_{4}\right](0.035 \mathrm{mmol}, 41 \mathrm{mg}), \mathrm{CuI}(0.02 \mathrm{mmol}, 3.81 \mathrm{mg})$, freshly distilled THF $(5 \mathrm{~mL})$, toluene $(5 \mathrm{~mL})$, and triethylamine $(5 \mathrm{~mL})$. The resulting suspension was deaerated by bubbling argon at $80^{\circ} \mathrm{C}$ for $20 \mathrm{~min}$. The reaction mixture was stirred at room temperature for one day. After re- moval of the solvents at reduced pressure, the residue was washed with water $(100 \mathrm{~mL})$ and extracted into $\mathrm{CHCl}_{3}$. The organic layer was dried on $\mathrm{Na}_{2} \mathrm{SO}_{4}$ and the solvent was removed under reduced pressure. Column chromatographic separation of the residue on silica gel using $\mathrm{CHCl}_{3}$ as the eluant yielded the desired product as an orange solid (95 mg, $65 \%$ ). ${ }^{1} \mathrm{H}$ NMR (400 MHz, $\mathrm{CDCl}_{3}$ ): $\delta=7.76$ (s, 3H, ArH), 7.69 $(\mathrm{d}, 6 \mathrm{H}, J=8.2 \mathrm{~Hz}, \mathrm{ArH}), 7.34(\mathrm{~d}, 6 \mathrm{H}, J=8.1 \mathrm{~Hz}, \mathrm{ArH}), 2.56(\mathrm{~s}, 18 \mathrm{H}$, $\left.\mathrm{CH}_{3}\right), 2.34\left(\mathrm{q}, 12 \mathrm{H}, J=7.5 \mathrm{~Hz}, \mathrm{CH}_{2}\right), 1.36\left(\mathrm{~s}, 18 \mathrm{H}, \mathrm{CH}_{3}\right), 1.01 \mathrm{ppm}(\mathrm{t}$, $\left.18 \mathrm{H}, J=7.5 \mathrm{~Hz}, \mathrm{CH}_{3}\right) ;{ }^{13} \mathrm{C}$ NMR $\left(100 \mathrm{MHz}, \mathrm{CDCl}_{3}\right): \delta=154.1,139.0$, 138.1, 136.4, 134.3, 133.0, 132.3, 130.5, 128.7, 123.9, 123.3, 90.2, 88.8, 17.1, 14.5, 12.5, $11.9 \mathrm{ppm}$; MS (TOF-ESI): $\mathrm{m} / \mathrm{z}$ calcd for $\mathrm{C}_{81} \mathrm{H}_{81} \mathrm{~B}_{3} \mathrm{~F}_{6} \mathrm{~N}_{6}$ : $1284.6706[\mathrm{M}]^{+}$; found: $1284.6706[\mathrm{M}]^{+}$.

Synthesis of compound 4: In a $50 \mathrm{~mL}$ Schlenk tube were added 1 (0.442 mmol, $0.224 \mathrm{~g}), 1,2,4,5$-tetraethynylbenzene $(0.099 \mathrm{mmol}, 17.3 \mathrm{mg})$, $\left[\mathrm{Pd}\left(\mathrm{PPh}_{3}\right)_{4}\right](0.04 \mathrm{mmol}, 46.2 \mathrm{mg})$, CuI $(0.023 \mathrm{mmol}, 4.34 \mathrm{mg})$, freshly distilled THF $(5 \mathrm{~mL})$, toluene $(5 \mathrm{~mL})$, and triethylamine $(5 \mathrm{~mL})$. The resulting suspension was deaerated by bubbling argon at $80^{\circ} \mathrm{C}$ for $20 \mathrm{~min}$. The reaction mixture was stirred at room temperature for one day. After removal of the solvents at reduced pressure, the residue was washed with water $(100 \mathrm{~mL})$ and extracted into $\mathrm{CHCl}_{3}$. The organic layer was dried on $\mathrm{Na}_{2} \mathrm{SO}_{4}$ and the solvent was removed under reduced pressure. Column chromatographic separation of the residue on silica gel using $\mathrm{CHCl}_{3}$ as the eluant yielded the desired product as an orange solid. $(100 \mathrm{mg}, 60 \%) .{ }^{1} \mathrm{H}$ NMR $\left(400 \mathrm{MHz}, \mathrm{CDCl}_{3}\right): \delta=7.90(\mathrm{~s}, 2 \mathrm{H}, \mathrm{ArH}), 7.74$ $(\mathrm{d}, 8 \mathrm{H}, J=8.3 \mathrm{~Hz}, \operatorname{ArH}), 7.34(\mathrm{~d}, 8 \mathrm{H}, J=8.3 \mathrm{~Hz}, \mathrm{ArH}), 2.55(\mathrm{~s}, 24 \mathrm{H}$, $\left.\mathrm{CH}_{3}\right), 2.30\left(\mathrm{q}, 16 \mathrm{H}, J=7.5 \mathrm{~Hz}, \mathrm{CH}_{2}\right), 1.35\left(\mathrm{~s}, 24 \mathrm{H}, \mathrm{CH}_{3}\right), 0.97 \mathrm{ppm}(\mathrm{t}$, $\left.24 \mathrm{H}, J=7.6 \mathrm{~Hz}, \mathrm{CH}_{3}\right) ;{ }^{13} \mathrm{C} \mathrm{NMR}\left(100 \mathrm{MHz}, \mathrm{CDCl}_{3}\right): \delta=154.3,138.8$, 138.0, 136.7, 133.2, 132.3, 130.5, 128.8, 125.4, 123.3, 95.3, 88.5, 17.1, 14.5, 12.5, $11.9 \mathrm{ppm}$; MS HRMS (TOF-ESI): $\mathrm{m} / z$ calcd for $\mathrm{C}_{106} \mathrm{H}_{106} \mathrm{~B}_{4} \mathrm{~F}_{8} \mathrm{~N}_{8}$ : $1686.8785[M]^{+}$; found: $1686.8794[M]^{+}$.

Synthesis of compound 5: In a $100 \mathrm{~mL}$ round-bottomed flask equipped with a Dean-Stark trap and a reflux condenser were added benzene $(40 \mathrm{~mL}), 2(0.17 \mathrm{mmol}, 0.150 \mathrm{~g}), 4$-methoxybenzaldehyde $(0.17 \mathrm{mmol}$, $23.12 \mathrm{mg}$ ), acetic acid $(0.5 \mathrm{~mL})$, and piperidine $(0.5 \mathrm{~mL})$. The reaction mixture was stirred at reflux temperature and concentrated nearly to dryness. Progress of the reaction was monitored by TLC ( $3: 1$ hexanes:ethyl acetate). When all the starting material had been consumed, water $(100 \mathrm{~mL})$ was added and the mixture was extracted into $\mathrm{CHCl}_{3}$. The organic layer was dried on $\mathrm{Na}_{2} \mathrm{SO}_{4}$ and the solvent was removed under reduced pressure. Column chromatographic separation (silica gel, 3:1 hexanes:ethyl acetate) and preparative TLC (silica gel, benzene) of the residue yielded the desired product as a violet solid. (35 mg, $20 \%$ ). ${ }^{1} \mathrm{H}$ NMR $\left(400 \mathrm{MHz}, \mathrm{CDCl}_{3}\right): \delta=7.69$ (d, $\left.2 \mathrm{H}, J=8.3 \mathrm{ArH}\right), 7.68(\mathrm{~d}, 2 \mathrm{H}, J=8.2$ $\operatorname{ArH}), 7.63(\mathrm{~d}, 1 \mathrm{H}, J=17.0 \mathrm{~Hz}, \mathrm{CH}), 7.59(\mathrm{~s}, 4 \mathrm{H}, \mathrm{ArH}), 7.56(\mathrm{~d}, 2 \mathrm{H}, J=$ $8.7 \mathrm{~Hz}, \mathrm{ArH}), 7.35$ (d, $2 \mathrm{H}, J=7.9 \mathrm{ArH}), 7.32(\mathrm{~d}, 2 \mathrm{H}, J=8.0 \mathrm{~Hz}, \mathrm{ArH})$, $7.21(\mathrm{~d}, 1 \mathrm{H}, J=16.5 \mathrm{~Hz}, \mathrm{CH}), 6.93(\mathrm{~d}, 2 \mathrm{H}, J=8.8 \mathrm{~Hz}, \mathrm{ArH}), 3.85(\mathrm{~s}, 3 \mathrm{H}$, $\left.\mathrm{OCH}_{3}\right), 2.62\left(\mathrm{q}, 2 \mathrm{H}, J=6.1 \mathrm{~Hz}, \mathrm{CH}_{2}\right), 2.60\left(\mathrm{~s}, 3 \mathrm{H}, \mathrm{CH}_{3}\right), 2.55(\mathrm{~s}, 6 \mathrm{H}$, $\left.\mathrm{CH}_{3}\right), 2.33\left(\mathrm{q}, 6 \mathrm{H}, J=6.1 \mathrm{~Hz}, \mathrm{CH}_{2}\right), 1.49\left(\mathrm{~s}, 3 \mathrm{H}, \mathrm{CH}_{3}\right), 1.37\left(\mathrm{~s}, 3 \mathrm{H}, \mathrm{CH}_{3}\right)$, $1.35\left(\mathrm{~s}, 6 \mathrm{H}, \mathrm{CH}_{3}\right), 1.17$ (t, $\left.3 \mathrm{H}, J=7.5 \mathrm{~Hz}, \mathrm{CH}_{3}\right), 1.05-0.97 \mathrm{ppm}(\mathrm{m}, 9 \mathrm{H}$, $\left.\mathrm{CH}_{3}\right) ;{ }^{13} \mathrm{C}$ NMR $\left(100 \mathrm{MHz}, \mathrm{CDCl}_{3}\right): \delta=160.1,136.3,136.1,135.1,132.3$, 131.7, 130.3, 128.9, 128.7, 123.6, 123.1, 114.2, 90.8, 90.3, 90.2, 55.4, 18.3, 17.1, 17.0, 14.6, 14.5, 14.1, 12.6, 11.9, $11.7 \mathrm{ppm}$; MS (TOF-ESI): $\mathrm{m} / z$ calcd for $\mathrm{C}_{64} \mathrm{H}_{62} \mathrm{~B}_{2} \mathrm{~F}_{4} \mathrm{O}: 1000.5046[M]^{+}$; found: $1000.5061[\mathrm{M}]^{+}$.

Synthesis of compound 6: In a $100 \mathrm{~mL}$ round-bottomed flask equipped with a Dean-Stark trap and a reflux condenser were added benzene $(40 \mathrm{~mL}), 3(0.047 \mathrm{mmol}, 60 \mathrm{mg}), 4$-methoxybenzaldehyde $(0.047 \mathrm{mmol}$, $6.36 \mathrm{mg})$, acetic acid $(0.2 \mathrm{~mL})$, and piperidine $(0.2 \mathrm{~mL})$. The reaction mixture was stirred at reflux temperature and concentrated nearly to dryness. Progress of the reaction was monitored by TLC ( $4: 1$ hexanes:ethyl acetate). When all the starting material had been consumed, water $(100 \mathrm{~mL})$ was added and the mixture was extracted into $\mathrm{CHCl}_{3}$. The organic layer was dried on $\mathrm{Na}_{2} \mathrm{SO}_{4}$ and the solvent was removed under reduced pressure. Column chromatographic separation (silica gel, 4:1 hexanes:ethyl acetate) of the residue yielded the desired product as a violet solid. $(19.8 \mathrm{mg}, 30 \%) .{ }^{1} \mathrm{H}$ NMR $\left(400 \mathrm{MHz}, \mathrm{CDCl}_{3}\right): \delta=7.77$ (s, $\left.3 \mathrm{H}, \mathrm{ArH}\right)$, 7.73-7.67 (m, 6H, ArH), $7.64(\mathrm{~d}, 1 \mathrm{H}, J=16.7 \mathrm{~Hz}, \mathrm{CH}), 7.57(\mathrm{~d}, 2 \mathrm{H}, J=$ $8.8 \mathrm{~Hz}, \operatorname{ArH}), 7.38-7.32(\mathrm{~m}, 6 \mathrm{H}, \operatorname{ArH}), 7.21(\mathrm{~d}, 1 \mathrm{H}, J=17.5 \mathrm{~Hz}, \mathrm{CH})$, $6.93(\mathrm{~d}, 2 \mathrm{H}, J=8.9 \mathrm{~Hz}, \mathrm{ArH}), 3.85\left(\mathrm{~s}, 3 \mathrm{H}, \mathrm{OCH}_{3}\right), 2.67-2.58(\mathrm{~m}, 5 \mathrm{H}$, 
$\mathrm{CH}_{2}$ and $\left.\mathrm{CH}_{3}\right), 2.55$ (s, $12 \mathrm{H}, \mathrm{CH}_{3}$ ), 2.33 (q, $10 \mathrm{H}, J=7.3 \mathrm{~Hz}, \mathrm{CH}_{2}$ ), 1.40$1.32\left(\mathrm{~m}, 18 \mathrm{H}, \mathrm{CH}_{3}\right), 1.17\left(\mathrm{t}, 3 \mathrm{H}, J=7.5 \mathrm{~Hz}, \mathrm{CH}_{3}\right), 1.05-0.95 \mathrm{ppm}(\mathrm{m}$, $\left.15 \mathrm{H}, \mathrm{CH}_{3}\right) ;{ }^{13} \mathrm{C}$ NMR $\left(100 \mathrm{MHz}, \mathrm{CDCl}_{3}\right): \delta=165.0,160.2,154.2,138.2$, 136.4, 135.2, 134.4, 133.0, 132.3, 131.6, 130.5, 129.0, 128.7, 128.6, 124.0, 123.3, 123.2, 118.0, 117.8, 114.2, 90.2, 88.8, 55.4, 21.0, 18.6, 17.1, 14.6, 14.4, 14.2, 14.1, 12.5, 11.9 ppm; MS (TOF-ESI): $m / z$ calcd for $\mathrm{C}_{89} \mathrm{H}_{87} \mathrm{~B}_{3} \mathrm{~F}_{6} \mathrm{~N}_{6} \mathrm{O}$ : $1402.7125[M]^{+}$; found: $1402.7073[M]^{+}$

Synthesis of compound 7: In a $100 \mathrm{~mL}$ round-bottomed flask equipped with a Dean-Stark trap and a reflux condenser were added benzene $(40 \mathrm{~mL}), 4(0.13 \mathrm{mmol}, 0.220 \mathrm{~g}), 4$-methoxybenzaldehyde $(0.13 \mathrm{mmol}$, $17.7 \mathrm{mg})$, acetic acid $(0.5 \mathrm{~mL})$, and piperidine $(0.5 \mathrm{~mL})$. The reaction mixture was stirred at reflux temperature and concentrated nearly to dryness. Progress of the reaction was monitored by TLC (3:1 hexanes:acetone). When all the starting material had been consumed, water $(100 \mathrm{~mL})$ was added and the mixture was extracted into $\mathrm{CHCl}_{3}$. The organic layer was dried on $\mathrm{Na}_{2} \mathrm{SO}_{4}$ and the solvent was removed under reduced pressure. Column chromatographic separation (silica gel, 4:1 hexanes:acetone) of the residue yielded the desired product as a violet solid. ( $47 \mathrm{mg}, 20 \%$ ). ${ }^{1} \mathrm{H}$ NMR $\left(400 \mathrm{MHz}, \mathrm{CDCl}_{3}\right): \delta=7.90(\mathrm{~s}, 2 \mathrm{H}, \mathrm{ArH}), 7.74(\mathrm{~d}, 8 \mathrm{H}, J=$ $8.1 \mathrm{~Hz}, \mathrm{ArH}), 7.62(\mathrm{~d}, 1 \mathrm{H}, J=16.1 \mathrm{~Hz}, \mathrm{CH}), 7.56(\mathrm{~d}, 2 \mathrm{H}, J=8.8 \mathrm{~Hz}$, ArH), 7.38-7.32 (m, 8H, ArH), $7.19(\mathrm{~d}, 1 \mathrm{H}, J=16.3 \mathrm{~Hz}, \mathrm{CH}), 6.92(\mathrm{~d}$, $2 \mathrm{H}, J=8.6 \mathrm{~Hz}, \mathrm{ArH}), 3.85\left(\mathrm{~s}, 3 \mathrm{H}, \mathrm{OCH}_{3}\right), 2.63-2.56\left(\mathrm{~m}, 5 \mathrm{H}, \mathrm{CH}_{2}\right.$ and $\left.\mathrm{CH}_{3}\right), 2.54\left(\mathrm{~s}, 18 \mathrm{H}, \mathrm{CH}_{3}\right), 2.30\left(\mathrm{q}, 14 \mathrm{H}, J=7.4 \mathrm{~Hz}, \mathrm{CH}_{2}\right), 1.38(\mathrm{~s}, 3 \mathrm{H}$, $\left.\mathrm{CH}_{3}\right), 1.36-1.32\left(\mathrm{~m}, 21 \mathrm{H}, \mathrm{CH}_{3}\right), 1.14\left(\mathrm{t}, 3 \mathrm{H}, J=7.4 \mathrm{~Hz}, \mathrm{CH}_{3}\right), 0.96 \mathrm{ppm}$ (t, $\left.21 \mathrm{H}, J=7.6 \mathrm{~Hz}, \mathrm{CH}_{3}\right) ;{ }^{13} \mathrm{C}$ NMR $\left(100 \mathrm{MHz}, \mathrm{CDCl}_{3}\right): \delta=154.3,138.8$, 138.0, 137.9, 136.9, 136.7, 132.3, 129.1, 129.0, 128.8, 128.7, 125.5, 123.3, $114.2,95.3,93.3,88.5,55.4,17.1,17.0,16.8,16.7,16.5,14.6,14.5,14.4$, 14.1, 14.0, 12.6, 12.5, $11.9 \mathrm{ppm}$; MS HRMS (TOF-ESI): $\mathrm{m} / \mathrm{z}$ calcd for $\mathrm{C}_{114} \mathrm{H}_{112} \mathrm{~B}_{4} \mathrm{~F}_{8} \mathrm{~N}_{8} \mathrm{O}: 1804.9204[M]^{+}$; found: $1804.9136[M]^{+}$.

\section{Acknowledgements}

The authors gratefully acknowledge support from the Turkish Academy of Sciences (TUBA).

[1] a) R. Ziessel, G. Ulrich, A. Harriman, New J. Chem. 2007, 31, 496501; b) A. Loudet, K. Burgess, Chem. Rev. 2007, 107, 4891-4932; c) G. Ulrich, R. Ziessel, A. Harriman, Angew. Chem. 2008, 120, 1202-1219; Angew. Chem. Int. Ed. 2008, 47, 1184-1201.

[2] a) K. Rurack, M. Kollmannsberger, J. Daub, Angew. Chem. 2001, 113, 396-399; Angew. Chem. Int. Ed. 2001, 40, 385-387; b) G. Ulrich, C. Goze, M. Guardigli, A. Roda, R. Ziessel, Angew. Chem. 2005, 117, 3760-3764; Angew. Chem. Int. Ed. 2005, 44, 3694-3698; c) Z. Dost, S. Atilgan, E. U. Akkaya, Tetrahedron 2006, 62, 84848488; d) J.-S. Lee, N.-Y. Kang, Y. K. Kim, A. Samanta, S. Feng, H. K. Kim, M. Vendrell, J. H. Park, Y.-T. Chang, J. Am. Chem. Soc. 2009, 131, 10077-10082; e) J. Chen, M. Mizumura, H. Shinokubo, A. Osuko, Chem. Eur. J. 2009, 15, 5942-5949.

[3] a) M. Shah, K. Thangaraj, M.-L. L. T. Wolford, J. H. Boyer, I. R. Politzer, T. G. Pavlopoulos, Heteroat. Chem. 1990, 1, 389-399; b) T. Yogo, Y. Urano, Y. Ishitsuka, F. Maniwa, T. Nagano, J. Am. Chem. Soc. 2005, 127, 12162-12163; c) T. Rohand, M. Baruah, W. Qin, N. Boens, W. Dehaen, Chem. Commun. 2006, 266-268; d) C. Thivierge, R. Bandichhor, K. Burgess, Org. Lett. 2007, 9, 2135-2138; e) J. Y. Han, O. Gonzales, A. Aguilar-Aquilar, E. Pane-cabrera, K. Burgess, Org. Biomol. Chem. 2009, 7, 34-36.

[4] a) H. L. Kee, C. Kirmaier, L. Yu, P. Tamyougkit, W. J. Youngblood, M. E. Calder, L. Ramos, B. C. Noll, D. F. Bocian, W. R. Scheidt, R. R. Birge, J. S. Lindsey, D. Holten, J. Phys. Chem. A 2005, 109,
20433-20443; b) C. Goze, G. Ulrich, L. J. Mallon, B. D. Allen, A Harriman, R. Ziessel, J. Am. Chem. Soc. 2006, 128, 10231-10239; c) A. Harriman, G. Izzet, R. Ziessel, J. Am. Chem. Soc. 2006, 128 , 10868-10875; d) C. Tahtaoui, C. Thomas, F. Rohmer, P. Klotz, G. Duportail, Y. Mely, D. Bonnet, M. Hibert, J. Org. Chem. 2007, 72, 269-272.

[5] a) C.-W. Wan, A. Burghart, J. Chen, F. Bergström, L. B.-A. Johansson, M. F. Wolford, T. G. Kim, M. R. Topp, R. M. Hochstrasser, K. Burgess, Chem. Eur. J. 2003, 9, 4430-4441; b) E. Peña-Cabrera, A. Aguilar-Aguilar, M. Gonzalez-Dominguez, E. Lager, R. ZamudioVazquez, J. Godoy-Vargas, F. Villanueva-Garcia, Org. Lett. 2007, 9, 3985-3988; c) Y. Cakmak, E. U. Akkaya, Org. Lett. 2009, 11, 85-88.

[6] a) K. Umezawa, A. Matsui, Y. Nakamura, D. Citterio, K. Suzuki, Chem. Eur. J. 2009, 15, 1096-1106; b) K. Umezawa, Y. Nakamura, H. Makino, D. Citterio, K. Suzuki, J. Am. Chem. Soc. 2009, 131, $1550-1551$.

[7] a) K. Rurack, M. Kollmansberger, U. Resch-Genger, J. Daub, J. Am. Chem. Soc. 2000, 122, 968-969; b) A. Coskun, E. U. Akkaya, J. Am. Chem. Soc. 2005, 127, 10464-10465; c) A. Coskun, E. U. Akkaya, J. Am. Chem. Soc. 2006, 128, 14474-14475; d) H. Sunahara, Y. Urano, H. Kojima, T. Nagano, J. Am. Chem. Soc. 2007, 129, 5597-5604; e) A. Coskun, M. D. Yilmaz, E. U. Akkaya, Org. Lett. 2007, 9, 607609; f) S. Atilgan, T. Ozdemir, E. U. Akkaya, Org. Lett. 2008, 10, 4065-4067; g) T. W. Hudnall, F. P. Gabbai, Chem. Commun. 2008, 4596-4597; h) D. P. Kennedy, C. M. Kormos, S. C. Burdette, J. Am Chem. Soc. 2009, 131, 8578-8586; i) R. Guliyev, O. Buyukcakir, F. Sozmen, O. A. Bozdemir, Tetrahedron Lett. 2009, 50, 5139-5141; j) Y. Shiraishi, H. Maehara, T. Sugii, D. P. Wang, T. Hirai, Tetrahedron Lett. 2009, 50, 4293-4296; k) R. Guliyev, A. Coskun, E. U. Akkaya, J. Am. Chem. Soc. 2009, 131, 9007-9013.

[8] a) A. Gorman, J. Killoran, C. O'Shea, T. Kenna, W. M. Gallagher, D. F. O'Shea, J. Am. Chem. Soc. 2004, 126, 10619-10631; b) S. Atilgan, Z. Ekmekci, A. L. Dogan, D. Guc, E. U. Akkaya, Chem. Commun. 2006, 4398-4400; c) S. Ozlem, E. U. Akkaya, J. Am Chem. Soc. 2009, 131, 48-49; d) S. Erbas, A. Gorgulu, M. Kocakusakogullari, E. U. Akkaya, Chem. Commun. 2009, 4956-4958.

[9] a) A. Coskun, E. Deniz, E. U. Akkaya, Org. Lett. 2005, 7, $5187-$ 5189; b) S. Hattori, K. Ohkubo, Y. Urano, H. Sunahara, T. Nagano, Y. Wada, N. V. Tkachenko, H. Lemmetyinen, S. Fukuzimi, J. Phys Chem. A 2005, 109, 15368-15375; c) K. Rurack, C. Trieflinger, A Koval'chuck, J. Daub, Chem. Eur. J. 2007, 13, 8998-9003; d) E. Deniz, G. C. Isbasar, O. A. Bozdemir, L. T. Yildirim, A. Siemiarczuk, E. U. Akkaya, Org. Lett. 2008, 10, 3401-3403; e) S. E. Ela, M. D. Yilmaz, B. Icli, Y. Dede, S. Icli, E. U. Akkaya, Org. Lett. 2008 , 10, 3299-3302; f) J. C. Forgie, P. J. Skabara, I. Stibor, F. Vilela, Z. Vobecka, Chem. Mater. 2009, 21, 1784-1786; g) O. A. Bozdemir, O. Buyukcakir, E. U. Akkaya, Chem. Eur. J. 2009, 15, 3830-3838.

[10] a) M. D. Yilmaz, O. A. Bozdemir, E. U. Akkaya, Org. Lett. 2006, 8, 2871-2873; b) A. Harriman, L. Mallon, R. Ziessel, Chem. Eur. J. 2008, 14, 11461-11473; c) X. Zhang, Y. Xiao, X. Qian, Org. Lett. 2008, 10, 29-32; d) J.-Y. Liu, H.-S. Yeung, W. Xu, X. Li, D. K. P. Ng, Org. Lett. 2008, 10, 5421-5424; e) M. Yuan, X. Yin, H. Zheng, C. Quyang, Z. Zuo, H. Liu, Y. Li, Chem. Asian J. 2009, 4, 707-713; f) S. Diring, F. Puntoriero, F. Nastasi, S. Campagna, R. Ziessel, J Am. Chem. Soc. 2009, 131, 6108-6109; g) G. Barin, M. D. Yilmaz, E. U. Akkaya, Tetrahedron Lett. 2009, 50, 1738-1740.

[11] S. Leininger, P. J. Stang, Organometallics 1998, 17, 3981-3987.

[12] O. Buyukcakir, O. A. Bozdemir, S. Kolemen, S. Erbas, E. U. Akkaya, Org. Lett. 2009, 11, 4644-4647.

Received: December 16, 2009 Published online: April 16, 2010 